\title{
АНАЛІЗ СТАНУ МОЛОЧНОГО СКОТАРСТВА УКРӒ̈НИ, ЯК ПЕРСПЕКТИВНОГО СЕКТОРА ЕКОНОМІКИ
}

Ковальчук Ігор Васильович

кандидат сільськогосподарських наук, доцент, Житомирський національний агроекологічний університет ORCID: https://orcid.org/0000-0002-5775-4140

E-mail : lkovalchuk_08@ukr.net

Слюсар Микола Вікторович кандидат сільськогосподарських наук, ст. викладач Житомирський національний агроекологічний університет ORCID: https://orcid.org/0000-0002-3668-2109

E-mail: slusar_nv@ukr.net

Ковальчук Ірина Ігорівна кандидат ветеринарних наук, ст. викладач Житомирський національний агроекологічний університет ORCID: https://orcid.org/0000-0002-2421-7533 E-mail: irinakovalchuk82@mail.ru

Об'єктом досліджень була галузь молочного скотарства України. Метою роботи було проаналізувати стан галузі молочного скотарства в Україні, визначення проблем та шляхів подолання кризового стану. Галузь молочного скотарства в Україні характеризується скороченням поголів'я худоби, зменшенням загального обсягу виробництва молока. Втрата молочних корів - це втрата стратегічних ресурсів, відновлення яких у найближчому майбутньому досить проблематичне. Тому стабілізація поголів'я і розвиток молочного скотарства повинні стати важливим пріоритетом аграрного виробництва. Тенденції структури виробництва молока засвідчують поступове нарощування його обсягів великими сільськогосподарськими підприємствами, що є позитивним з точки зору якості молока, економічної ефрективності його виробництва. Основними напрямами розвитком молочного скотарства є зосередження уваги на розширенні виробництва молока у великих господарствах. Для підтримання необхідного рівня виробництва молочної сировини молокопереробні підприємства продовжуватимуть ініціювати і фінансувати незалежність країни у даному сегменті національного агропродовольчого ринку, а також захист його від неякісної імпортної продукції; контролювати дотримання екологічних нормативів і протиепідеміологічних заходів, особливо крупними товаровиробниками, що, як правило, розміщують свої виробниитва поблизу великих населених пунктів. Основу молочного скотарства повинні становити вітчизняні породи, які за генетичним потенціалом знаходяться на рівні кращих європейських аналогів, а за якістю молока, плодючістю, тривалістю продуктивного використання їх переважають. Кількість і якість молочної сировини, що виробляється сьогодні в Україні, не відповідає вимогам ринку. Основними причинами цього є дрібнотоварність виробництва молока, концентрація його переважно у господарствах населення, постійне скорочення молочного поголів'я, низька ефективність селекційної роботи, дефіцит коштів для впровадження передових технологій годівлі, утримання та відтворення стада, відсутність економічних і соціальних стимулів покращення організації праці у молочному тваринництві, зокрема, низький рівень заробітної плати, несприятливі умови праці на селі тощо. Подальше поліпшення ситуації у молочному скотарстві вимагає державного стимулювання виробників шляхом підтримки їх діяльності.

Ключові слова: велика рогата худоба, продуктивність, молочне скотарство, сільськогосподарські підприємства, молоко, яловичина.

DOI: https://doi.org/10.32845/bsnau.Ivst.2019.4.9

Основу повноцінного харчування населення становлять молоко і молочні продукти. За науково обгрунтованими нормами харчування людина має споживати в середньому 380 кг (у перерахунку на молоко) молока і молочних продуктів, у тому числі 120 кг молока у свіжому вигляді [2]. Щоб забезпечити потребу населення у молочній продукції сучасна стратегія соціально-економічного розвитку України повинна передбачати нарощування агропромислового потенціалу країни.

Дослідженню стану молочного скотарства та перспектив його розвитку приділено увагу в роботах багатьох науковців. Серед останніх досліджень варто відмітити праці В. Гутович, Д.К. Семенди, О.В. Семенди, В.В. Антощенкової, та багатьох інших науковців $[4,5]$.

Вісник Сумського національного аграрного університету

Однак становище галузі молочного тваринництва з кожним роком ускладнюється, а Україна нажаль все більше орієнтується на імпорт молочної продукції вказуючи на незадовільну роботу національної молокопереробної галузі, яка не в змозі задовольнити потреби внутрішнього ринку. 3 кожним роком українська молочна галузь втрачає можливості і здатність конкурувати навіть на вітчизняному ринку молочної продукції. Нажаль, про забезпечення виробництва, яке повинно бути соціально орієнтованим на зростання здорового суспільства та яке не приносить матеріальної вигоди i, більше того, потребує фінансової допомоги та контролю, сучасному бізнесу просто не цікаве [14].

Втрата молочних корів - це втрата стратегічних ресурсів, відновлення яких у найближчому майбутньому до- 
сить проблематичне. Тому стабілізація поголів'я і розвиток молочного скотарства повинні стати важливим пріоритетом аграрного виробництва. Інтенсифікація молочного скотарства шляхом створення сучасної матеріально-технічної бази $є$ основним шляхом підвищення ефективності виробництва молока [2, 8].

При вирішенні проблеми збільшення виробництва молока виникає питання про вибір напряму. Із закономірностей послідовної інтенсифікації випливає об'єктивна необхідність поєднання зростання продуктивності та поступового збільшення поголів'я корів. У тваринництві можлива більш вузька спеціалізація, ніж у рослинництві, так як виробництво кількох видів продукції тваринництва може бути прямо не пов'язане з землею $[9,13]$. Це відноситься до сільськогосподарських підприємств, що спеціалізуються на інтенсивному молочному скотарстві. Різке зниження поголів'я корів та їх продуктивності часто обумовлено недоліком повноцінних кормів. Таким чином, можна зробити висновок про необхідність доведення чисельності поголів'я корів до оптимальних розмірів при прагненні отримувати максимальну продуктивність, а також кращого використання наявних кормових ресурсів [12]. Тому, есфективність інтенсифікації виробництва у тваринницькій галузі вирішальною мірою визначається наявністю кормової бази, що дозволяє здійснити повноцінну, збалансовану годівлю тварин [7]. В основу інтенсиффікації повинно бути покладене комплексне вирішення питань на основі наукової системи ведення господарства, галузей,

здійснення процесів розширеного відтворення [2, 13].

Мета роботи полягала у дослідженні сучасного стану галузі молочного скотарства в Україні, визначення проблем та шляхів подолання кризового стану.

Матеріали досліджень. слугувала інформація статистичного збірника України [8] щодо наявного поголів'я корів та виробництва молока, яка піддана селекційногенетичному, технологічному та економічному аналізу.

Результати дослідження. Аналіз останніх даних свідчить, що на початок 90-х років XX століття галузь молочного скотарства характеризувалася інтенсивним напрямом розвитку. Зокрема, в 1990 р. поголів'я великої рогатої худоби становило 24,6 млн. голів, в т.ч. 8,378 млн. корів, валове виробництво молока - 24,5 млн. т, яловичини і телятини 1,985 млн. т. виробництво молока на 100 га с.-г. -587 ц. м'яса ВРX - 154 ц.

На 100 осіб населення припадало 47 голів великої рогатої худоби в т.ч. 16 корів. Виробництво молока на одну особу становило 472 кг, м'яса - 84 кг [1,9].

Однак у наступні десятиліття відбулося практично повне руйнування організаційно-економічного механізму виробництва та переробки молока та яловичини, втрачено традиції кооперації та інтеграції в м'ясо-молочній промисловості.

Для прийняття вмотивованих управлінських рішень важливим $€$ аналіз динаміки розвитку галузі за останні роки (табл. 1.).

Таблиця 1

Поголів'я великої рогатої худоби в Україні, тис. гол

\begin{tabular}{|c|c|c|c|c|c|c|c|}
\hline \multirow{2}{*}{ Pik } & \multirow{2}{*}{$\begin{array}{l}\text { Всі категорії } \\
\text { господарств }\end{array}$} & \multicolumn{6}{|c|}{ У тому числі: } \\
\hline & & с.-г. підпри-ємства & питома вага & $\%$ до $2000 \mathrm{p}$. & господарства населення & питома вага & $\%$ до $2000 p$ \\
\hline \multicolumn{8}{|c|}{ Всього великої рогатої худоби } \\
\hline 2000 & 9423,7 & 5037,3 & 53,5 & 100 & 4386,4 & 46,5 & 100 \\
\hline 2010 & 4494,4 & 1526,4 & 34,0 & 30,3 & 2968,0 & 66,0 & 67,6 \\
\hline 2015 & 3750,3 & 1270,5 & 33,9 & 25,2 & 2479,8 & 66,1 & 56,5 \\
\hline 2016 & 3682,3 & 1213,0 & 33,0 & 24,0 & 2468,4 & 67,0 & 56,2 \\
\hline 2017 & 3530,8 & 1166,6 & 33,0 & 23,0 & 2364,2 & 66,9 & 53,8 \\
\hline \multicolumn{8}{|c|}{ Чисельність поголів'я корів } \\
\hline 2000 & 5958,3 & 1851,0 & 37,3 & 100 & 3107,3 & 62,7 & 100 \\
\hline 2010 & 2631,2 & 589,1 & 22,4 & 31,8 & 2042,1 & 77,6 & 65,7 \\
\hline 2015 & 2166,6 & 505,1 & 23,3 & 27,3 & 1661,5 & 76,7 & 53,5 \\
\hline 2016 & 2108,9 & 484,6 & 23,0 & 26,2 & 1624,3 & 77,0 & 52,3 \\
\hline 2017 & 2017,8 & 466,6 & 23,1 & 25,2 & 1551,2 & 76,9 & 49,9 \\
\hline
\end{tabular}

За 2000-2017 роки відбулося зменшення поголів'я великої рогатої худоби в усіх категоріях господарств в цілому на 5712,9 тис. голів (-62,6\%). 3 них у сільськогосподарських підприємствах з 5037,3 тис. до 1166,6 (-73\%), у господарствах населення - 3 4386,4 до 2364,2 тис. гол. (-46,2\%).

На 1 липня 2019 року поголів'я великої рогатої худоби України становило в сільськогосподарських підприємствах 1,12 млн. голів $(-5,4 \%)$, господарствах населення 2,62 млн. гол. (-3,5\%), а в цілому на 4,1\% менше, ніж на 1 липня
2018 року $[4,8]$.

Таким чином спостерігається притаманна багатьом країнам тенденція до скорочення поголів'я. Проте для України вона набуває істотних, загрозливих для продовольчої безпеки та експортного потенціалу розмірів.

Поряд із значним зниженням поголів'я корів виробництво молока зменшилося у 1,2 рази з 12,6 до 10,3 млн. (табл.2)

Виробництво молока за категоріями господарств

Таблиця 2

\begin{tabular}{|c|c|c|c|c|c|c|c|}
\hline \multirow{2}{*}{ Рік } & \multirow{2}{*}{$\begin{array}{l}\text { Всі категорії } \\
\text { господарств }\end{array}$} & \multicolumn{6}{|c|}{ У тому числі: } \\
\hline & & с.-г. підприємства & їх питома вага & до 2000 р., \% & господарства населення & їх питома вага & до 2000 р., \% \\
\hline 2000 & 12657,9 & 3668,7 & 29,0 & 100 & 8989,2 & 71,0 & 100 \\
\hline 2010 & 11248,5 & 2216,6 & 19,7 & 60,4 & 9031,9 & 80,3 & 100,5 \\
\hline 2015 & 10615,4 & 2669,5 & 25,2 & 72,8 & 7946,2 & 74,8 & 88,4 \\
\hline 2016 & 10381,5 & 2705,6 & 26,1 & 73,7 & 7675,9 & 73,9 & 85,4 \\
\hline 2017 & 10280,5 & 2765,7 & 26,9 & 75,4 & 7514,9 & 73,1 & 83,6 \\
\hline
\end{tabular}


Стабільна з 2010 року рентабельність виробництва молока невелика - 12,6 - 18,5\%, що не забезпечує достат-

ньої для притоку інвестицій привабливості галузі. (табл. 3.)

Таблиця 3

Поголів'я худоби, рентабельність та виробництво молока і м'яса в Україні

\begin{tabular}{|c|c|c|c|c|c|c|}
\hline \multirow{2}{*}{ Рік } & \multicolumn{2}{|c|}{ Поголів'я тварин на початок року } & \multicolumn{2}{c|}{ Виробництво, тис. тонн } & \multicolumn{2}{c|}{ Рентабельність виробництва продукції у с.-г. підприємствах, \%: } \\
\cline { 2 - 7 } & великої рогатої худоби & корів & $\begin{array}{c}\text { яловичини і } \\
\text { телятини }\end{array}$ & молока & яловичини & молока \\
\hline 2010 & 4826,7 & 2736,5 & 2059,0 & 11248,5 & $-35,9$ & 17,9 \\
\hline 2013 & 4645,9 & 2554,3 & 2389,4 & 11488,2 & $-43,3$ & 13,6 \\
\hline 2015 & 3884,0 & 2262,7 & 2322,6 & 10615,4 & $-17,9$ & 12,6 \\
\hline 2016 & 3750,3 & 2166,6 & 2323,6 & 10381,5 & $-24,8$ & 18,2 \\
\hline
\end{tabular}

Підвищення продуктивності корів у сільськогосподарських підприємствах обумовлено належними технологічними можливостями для забезпечення умов ефективного ведення молочного скотарства, а також використання кращих вітчизняних і зарубіжних порід. Зокрема, за даними М.Гладія та ін. (2018) у породній структурі худоби, більше половини $(53,4 \%)$ припадає на українську чорно-рябу молочну породу. Середній надій племінних корів цієї породи за 10 років виріс на 47,3\%. Відносно скоротилась частка підконтрольних корів українських червоно-рябої (до 18,1\%) та червоної $(4,8 \%)$ молочних, червоної степової $(1,3 \%)$ та симентальської (до 3,6\%) порід за підвищення надоїв відпо- відно на 42,3\%, 49,2\%, 17,4\% і 58,3\%. При цьому, більше ніж удвічі (до 16,2\%) зросла частка голштинської породи, середній надій корів якої за 10 років зріс на $35,1 \%$. У середньому за всіма породами надій племінних корів наближається до 7 тонн, по голштинській породі перевищив 8 тонн. Але підвищення молочної продуктивності закономірно супроводжується зниженням виходу телят на 100 корів (з 81 за 2007 до 78 - у 2017 році) $[5,6]$.

Отже зростання поголів'я худоби у активній частині популяції у найближчій перспективі $€$ досить проблематичним з огляду на відтворні здатності маточного поголів'я та тривалість використання корів, які є недостатніми.

Таблиця 4

\section{Динаміка поголів'я та показників молочної продуктивності корів молочних порід} у племінних господарствах [2]

\begin{tabular}{|c|c|c|c|c|c|c|c|c|}
\hline \multirow{3}{*}{ Рік } & \multirow{3}{*}{ Число стад } & \multirow{3}{*}{ Поголів'я корів } & \multicolumn{6}{|c|}{ Продуктивність (за результатами бонітування) } \\
\hline & & & \multirow{2}{*}{$\begin{array}{c}\text { пробонітовано } \\
\text { корів }\end{array}$} & \multirow{2}{*}{ надій, кг } & \multicolumn{2}{|c|}{ вихід, кг } & \multicolumn{2}{|c|}{ вміст у молоці, \% } \\
\hline & & & & & жиру & білка & жиру & білке \\
\hline \multicolumn{9}{|c|}{ Українська чорно-ряба молочна } \\
\hline 2011 & 221 & 75535 & 60292 & 5493 & 204,7 & 178,3 & 3,73 & 3,24 \\
\hline 2014 & 195 & 69665 & 54888 & 6222 & 231,1 & 203,2 & 3,71 & 3,26 \\
\hline 2016 & 182 & 68778 & 53071 & 6606 & 245,1 & 216,1 & 3,71 & 3,27 \\
\hline \multicolumn{9}{|c|}{ Українська червоно-ряба молочна } \\
\hline 2011 & 107 & 31920 & 25751 & 5588 & 210,5 & 182,2 & 3,77 & 3,26 \\
\hline 2014 & 85 & 27860 & 21656 & 6232 & 234,7 & 202,4 & 3,78 & 3,24 \\
\hline 2016 & 76 & 25528 & 18952 & 6359 & 238,8 & 206,4 & 3,76 & 3,24 \\
\hline \multicolumn{9}{|c|}{ Українська червона молочна } \\
\hline 2011 & 29 & 9309 & 7199 & 5073 & 194,0 & 161,5 & 3,82 & 3,18 \\
\hline 2014 & 19 & 6334 & 4688 & 5971 & 232,4 & 193,9 & 3,88 & 3,24 \\
\hline 2016 & 19 & 6489 & 5117 & 5963 & 230,9 & 196,2 & 3,85 & 3,28 \\
\hline
\end{tabular}

В умовах сьогодення виробництво молока, молочних продуктів та їх споживання населенням не можна визнати задовільним $[7,15]$.

Зокрема, рівень забезпечення норми споживання становить всього 51-54\%. Основними причинами цього $є$ постійно зростаючі роздрібні ціни на молочну продукцію.

На переробні підприємства потрапляє близько $40 \%$ виробленого молока. Причому, із сільськогосподарських підприємств воно переробляється повністю, а з господарств населення - лише $17 \%$ [3].

За даними Міністерства аграрної політики у 2018 році молока екстра-гатунку надійшло на переробку 288 тис.т. (21\%), вищого - 533 тис. т. (39\%), I - 463 тис.т. (34\%), II - 81 тис.т. (6\%).

Середня реалізаційна ціна молока, проданого сільськогосподарськими підприємствами за всіма напрямами у січні - жовтні 2018 року по Україні становила 7491 грн/т.

Висновки. 1. Галузь молочного скотарства в Україні характеризується скороченням поголів'я худоби, зменшенням загального обсягу виробництва молока.
2. Кількість і якість молочної сировини, що виробляється сьогодні в Україні, не відповідає вимогам ринку. Основними причинами цього $€$ дрібнотоварність виробництва молока, концентрація його переважно у господарствах населення, постійне скорочення молочного поголів'я, низька ефективність селекційної роботи, дефріцит коштів для впровадження передових технологій годівлі, утримання та відтворення стада, відсутність економічних і соціальних стимулів покращення організації праці у молочному тваринництві, зокрема, низький рівень заробітної плати, несприятливі умови праці на селі тощо.

3. Роль господарств населення у забезпеченні товарних поставок молока у перспективі знизиться. Окремі виробники змушені будуть або об'єднатися у молочні кооперативи 3 метою виконання нормативних вимог до якості молочної сировини, або відмовитися від виходу на цивілізований ринок зі своєю продукцією і перейти в основному до виробництва її для задоволення власних потреб.

4. Тенденції структури виробництва молока засвідчують поступове нарощування його обсягів сільськогоспо- 
дарськими підприємствами, що є позитивним з точки зору якості молока, економічної ефективності його виробництва.

5. Основу молочного скотарства повинні становити вітчизняні породи, які за генетичним потенціалом знаходяться на рівні кращих європейських аналогів, а за якістю молока, плодючістю, тривалістю продуктивного використання їх переважають.

6. Основними напрямами розвитком молочного скотарства $є$ зосередження уваги на розширенні виробництва молока у великих господарствах.

7. Для підтримання необхідного рівня виробництва молочної сировини молокопереробні підприємства продовжуватимуть ініціювати і фінансувати незалежність країни у даному сегменті національного агропродовольчого ринку, а також захист його від неякісної імпортної продукції; контролювати дотримання екологічних нормативів і протиепідеміологічних заходів, особливо крупними товаровиробниками, що, як правило, розміщують свої виробництва поблизу великих населених пунктів.

8. Подальше поліпшення ситуації у молочному скотарстві вимагає державного стимулювання виробників шляхом підтримки їх діяльності.

\section{Список використаної літератури:}

1. Антощенкова В.В., Кравченко О.М. Економічна ефективність виробництва та реалізації молока в Україні. Актуальні проблеми інноваційної економіки. Х.: ХНТУСГ. 2016. №3, С. 39-44.

2. Антощенкова В.В. Стан та перспективи розвитку молочного скотарства України. Вісник Харківського національного аграрного університету ім. В.В. Докучаєва. Економічні науки. Х.: ХНАУ, 2015. № 1. С. 90-96.

3. Барилович О. М. Стан, проблеми та перспективи розвитку молочного скотарства. Науковий вісник Національного університету біоресурсів і природокористування України. Сер. : Економіка, аграрний менеджмент, бізнес, 2013. Вип. 181(6). C. 64-69. URL: http : // nbuv. gov. Ua / UJRN / nvnau_econ_2013_181(6)_11.

4. Бащенко М. І. Стан і перспективи розвитку молочного скотарства України. Розведення і генетика тварин, 2017. Вип. 54. С. 73-82.

5. Воляк Л. Р. Аналіз виробництва молока та молочних продуктів в Україні. Економіка і суспільство, 2018. Вип. 19. C. $1393-1399$. C. 14-20.

6. Гладій М. Генетичні ресурси молочного і м'ясного скотарства в Україні. Тваринництво України, 2018. Вип. №9-10.

7. Гутович В. Тваринництво: курс на відновлення галузі. Урядовий кур'єр, 2018.

8. Мазана Т. В., В.П. Ткаченко. Стан розвитку та проблеми молочного скотарства. Ефеективна економіка, 2013. Вип. 5. URL: http : // www. economy. nayka. com. ua/?op=1\&z=2069.

9. Молочне скотарство України: маркетингові дослідження. Вісник Харківського національного технічного університету сільського господарства імені Петра Василенка, 2016. Вип. 174. С. 74-82. URL: http : // nbuv. gov. Ua / UJRN / Vkhdtusg_2016_174_11.

10. Національний проект відродження скотарства URL: http://www.naas.gov.ua/content/literatura/1055/

11. Огляд молочного тваринництва. Тваринництво, молочне виробництво, 2019.

URL: http://milkua.info/uk/post/oglad-molocnogo-tvarinnictva-sicen-2019

12. Офріційний веб сайт Держкомстату України URL: http://www.ukrstat.gov.ua.

13. Семенда Д.К. Державна підтримка у відновленні галузі молочного скотарства Молодий вчений, 2018. № 3(1). C. $377-380$

14. Сконенко Н. С., Сучасний стан та тенденції розвитку молочної галузі Укараїни. URL: http : // ipdo. kiev. Ua / index. php? Option = com content \& view = article\&id=29.

15. Тваринництво України, статистичний збірник. Київ, 2018. 165с.

References:

1. Antoshchenkova V.V., Kravchenko O.M. Ekonomichna efektyvnist' vyrobnytstva ta realizatsiyi moloka v Ukrayini. Aktual'ni problemy innovatsiynoyi ekonomiky. KH.: KHNTUS·H. 2016. №3, S. 39-44.

2. Antoshchenkova V.V. Stan ta perspektyvy rozvytku molochnoho skotarstva Ukrayiny. Visnyk Kharkivs'koho natsional'noho ahrarnoho universytetu im. V.V. Dokuchayeva. Ekonomichni nauky. KH.: KHNAU, 2015. № 1. S. 90-96.

3. Barylovych O. M. Stan, problemy ta perspektyvy rozvytku molochnoho skotarstva. Naukovyy visnyk Natsional'noho universytetu bioresursiv i pryrodokorystuvannya Ukrayiny. Ser. : Ekonomika, ahrarnyy menedzhment, biznes, 2013. Vyp. 181(6). S. 64-69. URL: http : // nbuv. gov. Ua / UJRN / nvnau_econ. 2013. 181(6), pp.11.

4. Bashchenko M. I. Stan i perspektyvy rozvytku molochnoho skotarstva Ukrayiny. Rozvedennya i henetyka tvaryn, 2017. Vyp. 54. S. 73-82. 1393-1399.

5. Volyak L. R. Analiz vyrobnytstva moloka ta molochnykh produktiv v Ukrayini. Ekonomika i suspil'stvo, 2018. Vyp. 19. S. S. $14-20$.

6. Hladiy M. Henetychni resursy molochnoho i m"yasnoho skotarstva v Ukrayini. Tvarynnytstvo Ukrayiny, 2018. Vyp. №9-10.

7. Hutovych V. Tvarynnytstvo: kurs na vidnovlennya haluzi. Uryadovyy kur"yer, 2018.

8. Mazana T. V., V.P. Tkachenko. Stan rozvytku ta problemy molochnoho skotarstva. Efektyvna ekonomika, 2013. Vyp. 5. URL: http : // www. economy. nayka. com. ua/?op=1\&z=2069.

9. Molochne skotarstvo Ukrayiny: marketynhovi doslidzhennya. Visnyk Kharkivs'koho natsional'noho tekhnichnoho universytetu sil's'koho hospodarstva imeni Petra Vasylenka, 2016. Vyp. 174. S. 74-82. URL: http : // nbuv. gov. Ua / UJRN / 
Vkhdtusg_2016_174_11.

10. Natsional'nyy proekt vidrodzhennya skotarstva URL: http://www.naas.gov.ua/content/literatura/1055/

11. Ohlyad molochnoho tvarynnytstva. Tvarynnytstvo, molochne vyrobnytstvo , 2019. URL: http://milkua.info/uk/post/ogladmolocnogo-tvarinnictva-sicen-2019

12. Ofitsiynyy veb sayt Derzhkomstatu Ukrayiny URL: http://www.ukrstat.gov.ua.

13. Semenda D.K. Derzhavna pidtrymka u vidnovlenni haluzi molochnoho skotarstva Molodyy vchenyy, 2018. № 3(1). S. 377-380.

14. Skonenko N. S., Suchasnyy stan ta tendentsiyi rozvytku molochnoyi haluzi Ukarayiny. URL: http : // ipdo. kiev. Ua / index. php? Option $=$ com_ content \& view $=$ article\&id $=29$.

15. Tvarynnytstvo Ukrayiny, statystychnyy zbirnyk. Kyyiv, 2018. 165s.

\section{Kovalchuk I.V.,}

Slusar M.V.,

Kovalchuk I.I.

Analysis of the state of dairy cattle breeding in Ukraine, as a promising sector of the economy

The object of research was the dairy cattle industry of Ukraine. The purpose of the paper was to analyze the state of the dairy cattle industry in Ukraine, identify problems and ways to overcome the crisis. The dairy cattle industry in Ukraine is characterized by a decrease in the livestock population, a decrease in the total milk production. The loss of dairy cows is a waste of strategic resources, the recovery of which is quite problematic in the near future. Therefore, the stabilization of livestock and the development of dairy cattle should be an important priority for agricultural production. Trends in the structure of milk production testify to the gradual increase of its volumes by large agricultural enterprises, which is positive in terms of milk quality and economic efficiency of its production. The main trends in dairy cattle development are to focus on expanding milk production in large farms. To maintain the required level of dairy production, dairy enterprises will continue to initiate and finance the country's independence in this segment of the national agri-food market, as well as to protect it from substandard imported products; monitor compliance with environmental regulations and anti-epidemiological measures, especially by large producers, who typically locate their production near large settlements. The basis of dairy cattle should be domestic breeds, which by genetic potential are at the level of the best European analogues, and their quality, milk, fertility, duration of productive use make them superior. The quantity and quality of dairy raw materials produced in Ukraine today do not meet market requirements. The main reasons for this are the small-scale milk production, its concentration mainly in households, the constant reduction of dairy livestock, the low efficiency of breeding work, the lack of funds for the introduction of advanced feeding technologies, the maintenance and reproduction of the herd, the lack of economic and social incentives for improving the organization of labor. animal husbandry, in particular, low wages, poor working conditions in the countryside, etc. Further improvement of the situation in dairy cattle requires state incentives for producers to support their activities.

Key words: cattle, productivity, dairy cattle, agricultural enterprises, milk, beef.

Дата надходження до редакції: 24.10.2019 p. 